\title{
The role of tripartite concertation in the reform of the welfare state
}

\section{Summary}

Tripartite concertation, which has reappeared in several European countries, plays an important role in the current process of welfare reform. This article discusses the need to combine three different policy aims via social pacts between government, employers and trade unions: reducing labour costs, improving work incentives and increasing labour market flexibility. The article analyses two examples of successful social pacts: the Netherlands and Italy, both countries that first found a consensus on wage policy and then moved on to further reforms of welfare and employment policies. Thereafter, two examples of uncoordinated reform policies are discussed: Germany and France. We argue that two factors are particularly important for the success of concerted reform policies: the co-ordination capacity of collective organisations and the credible threat potential of state intervention in collective bargaining and social insurance governance.

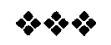

\section{Résumé}

La concertation tripartite, qui est réapparue dans plusieurs pays européens, joue un rôle important dans le processus actuel de la réforme de l'état providence. Cet article soulève la nécessité de combiner, via des pactes sociaux entre le gouvernement, les employeurs et les syndicats, trois objectifs politiques différents: réduire les coûts $d u$ travail, améliorer la motivation au travail et augmenter la flexibilité du marché du travail. L'article analyse deux exemples de pactes sociaux réussis : aux Pays-Bas et en Italie, deux pays qui ont d'abord trouvé un consensus sur la politique salariale et ensuite entrepris des réformes des politiques en matière d'emploi et de sécurité sociale. Par la suite, deux cas de politique de réforme non coordonnée sont discutés : ceux de l'Allemagne et de la France. Les auteurs affirment que deux facteurs sont particulièrement importants pour le succès des politiques concertées portant sur la réforme : la capacité de coordination des organisations collectives et le potentiel de menace crédible d'intervention de l'Etat dans les négociations collectives et la gestion de la sécurité sociale.

* Researchers, Max Planck Institute, Paulstrasse 3, D-50676 Cologne. 


\section{Zusammenfassung}

Konzertierungen zwischen Regierungen und Tarifparteien, die in den letzten Jahren in mehreren europäischen Ländern wieder zu beobachten sind, spielen in der Reform der Wohlfahrtsstaaten eine wichtige Rolle. Regierungen, Arbeitgeberverbände und Gewerkschaften versuchen, durch die Vereinbarung sogenannter sozialer Pakte drei unterschiedliche politische Ziele zu kombinieren: die Reduzierung von Arbeitskosten, die Verbesserung von Anreizen zur Arbeitsaufnahme und die Flexibilisierung der Arbeitsmärkte. Der Beitrag analysiert zwei Beispiele erfolgreicher sozialer Pakte: die Niederlande und Italien. In beiden Ländern wurde zunächst ein Konsens in der Lohnpolitik erzielt und später weitergehende Reformen in der Sozial- und Arbeitspolitik durchgeführt. Anschließend werden zwei Länder unkoordinierter Reformpolitik am Beispiel Deutschlands und Frankreichs dargestellt. Zwei Faktoren werden als besonders bedeutsam für den Erfolg konzertierter Politik herausgearbeitet: die Handlungsfähigkeit der Verbände und die glaubwürdige Androhung staatlicher Intervention in die Tarifpolitik und die Systeme sozialer Sicherung.

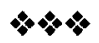

\section{Introduction}

Welfare reform and tripartite concertation are back on the political agenda. This seems to be somewhat paradoxical as long as one fails to perceive the link between the two processes.

The first paradox concerns welfare retrenchment: even "radical" welfare reforms of conservative governments fell short of what their rhetoric made the public believe. While the power of trade unions and left parties has shrunk considerably during the 1980s and 1990s, welfare cutbacks have been limited in scope (Pierson 1996). Welfare cuts were at best patchy, and in many cases welfare spending was not reduced but costs shifted to some groups, especially those welfare recipients without veto powers. Pierson - among others - has argued that radical welfare reforms were blocked because of the political costs involved, the widespread popularity of universal welfare programmes, and the mobilisation potential of well-organised clientele groups against cuts in welfare benefits. Instead of retrenchment, welfare reformers were able only to react piecemeal to the pressures of rising costs, demographic shifts, economic difficulties and fiscal strains. Whatever these pressures, we find a strong resilience of welfare states to keep their basic structure and there are few signs of structural reforms that bring about the necessary adjustment to the changing demographic and socio-economic environment. 
The other paradox is the "renaissance" of tripartite concertation between the government (Schmitter and Grote 1997), trade unions and employer confederations in many European countries in the 1990s, long after the end of corporatism had been declared (Lash and Urry 1987). The late 1980s and 1990s brought about new forms of tripartite agreements - so-called social pacts - in the Netherlands, Ireland, Italy, Portugal, Finland, and Belgium (Fajertag and Pochet 1997; Schmitter and Grote 1997; Hassel 1998). Interestingly, these agreements generally cover both wage policy and welfare reforms but they differ from the income policies of the 1970s, when governments promised the extension of social and labour rights as part of the "political exchange". Today, these social pacts envisage specific steps designed to find a new balance of wages and transfer payments in order to reduce overall labour costs and increase competitiveness.

Both phenomena lose their paradoxical nature, once their linkage is understood: the renewed interest in tripartite concertation is an attempt by many European governments to overcome barriers to welfare reform which have hampered such reforms and led to inflexible labour markets. By engaging in tripartite concertation with the main labour market actors, governments try to strike package deals in which the social partners accept certain welfare reforms in exchange for government concessions.

It is surprising that much of the current debate seems to have ignored the relevance of tripartite concertation for the reform of the welfare state. Social pacts are often seen as merely "tripartite agreements about wage restraint in exchange for employment" (Pochet and Fajertag 1997: 12). Wage restraint - as their main component is interpreted as the attempts by governments to improve their country's competitive position vis-à-vis neighbouring countries by lowering real unit labour costs in manufacturing industries (Schulten 1998). We believe, however, that the underlying logic of social pacts is misunderstood when we focus too narrowly on the issue of wage restraint alone. Similarly, many studies on welfare reform have concentrated on governmental policies, thereby often underestimating the importance of a social consensus and the linkage between the wage bargaining area and issues of social security reform.

Essentially we want to advance two arguments. First, we will indicate that besides wage restraint, the institutional regulation of welfare - consisting of labour market policies, social transfers and labour law - is an equally important aspect of social pacts, and largely interdependent. In order to get a grip on the dynamic of labour market and social security reforms in recent years, it seems crucial to understand the linkage between wage policy and social policy. 
Secondly, we will argue that the dynamics of tripartite concertation crucially depend on institutional factors such as the nature of trade unions and employers' associations, the role of the government, its relative autonomy, and its capacity to intervene in the collective bargaining realm of trade unions and employers. Since in many European countries trade unions and employers' confederations are heavily involved in the administration of social security funds and occupy many veto positions within the political system, their co-operation in tripartite concertation can only be assured if the government is strategic and autonomous enough to convincingly threaten the social partners. Successful welfare reforms which would have to break with the status quo require not only consensus-building but also the determination of governments to bring the social partners to accept a policy change.

In order to illustrate our two arguments, we will proceed in three steps. First, we elaborate the importance of welfare issues within social pacts and the relationship between social policy and wage policy. Secondly, we will look at 'successful' social pacts, that is, those pacts that remained stable and capable of delivering policy reform aims. We discuss the examples of the Netherlands and Italy. Thirdly, we will look at two examples where tripartite concertation has either failed in the past or where it has not been possible, namely, Germany and France. In conclusion, we will present some of the reasons why and how tripartite concertation can be successful or is doomed to fail.

\section{Welfare reform through tripartite concertation}

Many observers maintain that the main role of tripartite concertation is to improve a country's competitive position by lowering labour costs. Social pacts are commonly struck under crisis conditions, that is, increased competitive pressure and fiscal strains. They present a new form of 'competitive corporatism' in which governments "need to find partners in achieving broad macro-economic objectives at a time of difficult adjustment to the demands of European integration - especially the Maastricht convergence criteria for membership of EMU" (Rhodes 1997: 17). Yet the measures stipulated by these tripartite agreements do not easily fit the pure macro-economic interpretation of lowering labour costs and public debt. Important elements of tripartite agreements are both moderate wage agreements and a greater degree of flexibility in the labour market. But, in contradiction to cost-saving measures, these agreements often contain an extension of employment-creation programmes which are funded by public finances. In addition, they regularly include a commitment by the government to improve education and training, to lower taxation and social security contributions. In general, they involve rather complicated bargains in which the government has to take on quite 
substantial policy reforms in order to gain the acceptance of the collective bargaining partners.

When we put the policy contents of those pacts into the wider context of employment policy, it emerges that the reforms are generally addressed to the institutional aspects of the labour market. These policies are not new, but have become the main thrust of employment policy in the 1990s on the European and international level. Already in 1993, the White Paper of the EU Commission on Growth, Competitiveness and Employment spelled out the task of "fundamental changes in the labour market, which is not just deregulation, but a new system of regulation and incentives" (EU Commission 1993: 150). Subsequently, the Commission developed "Employment Guidelines" and aims at monitoring individual steps by EU member states in a 'bench-marking' process via National Action Plans (EU Commission 1997 and 1998). Also, the OECD Jobs Study summarises the main elements of labour market reform needed to foster employment growth: labour market flexibility, tax cuts, more wage differentiation and improved work incentives. The OECD also monitors the changes in these areas in the report 'Implementing the Jobs Study' (OECD 1997).

Figure 1: Welfare Reform Strategies and Policy Linkages in the 1990s

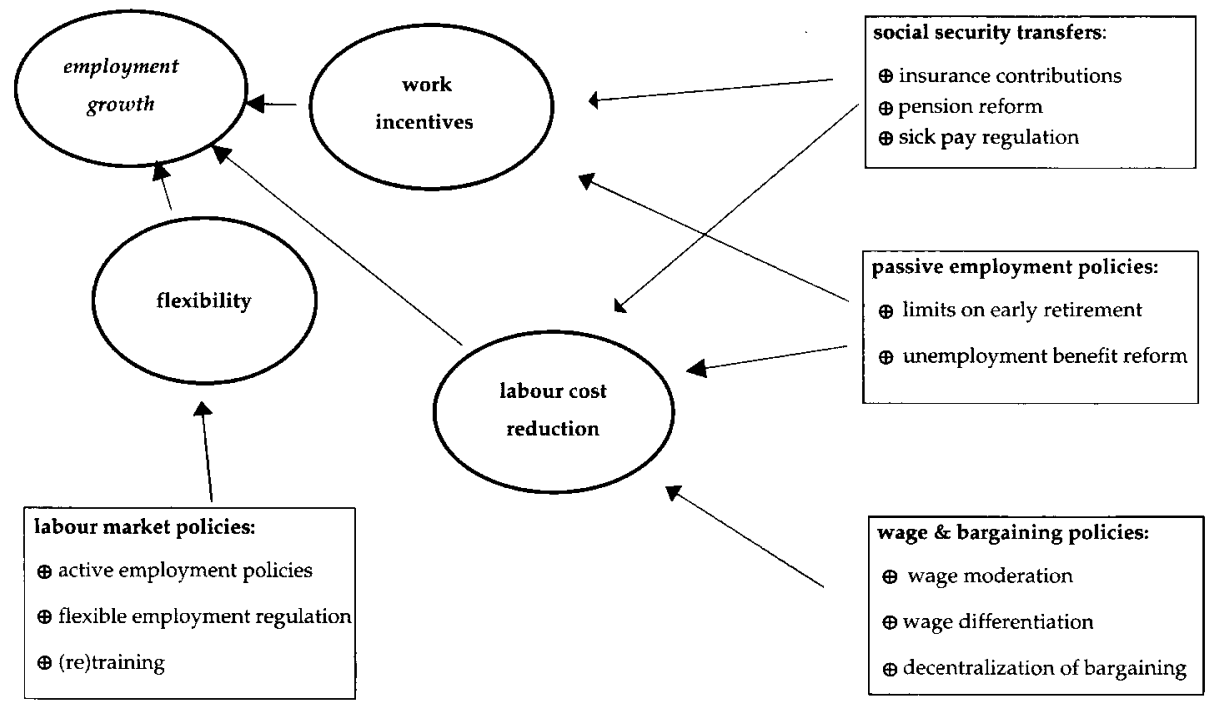


This reform debate - propagated and co-ordinated by international agencies - evolves around three policy aims: reducing labour costs, improving work incentives and increasing labour market flexibility. From the government's perspective all three issues serve - ideally - multiple purposes, which go beyond the narrow view of undercutting the labour costs of competing countries. Lowering real unit labour costs through wage moderation, for example, has a direct impact on export-oriented industries, but also an equally important moderating effect on the government's public sector wage bill. Lowering transfer payments will reduce the reservation wage and thus create more work incentives, which has the double effect of decreasing social expenditure and lowering (voluntary) unemployment. Measures such as extending the retirement age or allowing partial pensions increase the employment rate among elderly workers. These can be powerful instruments for alleviating the overburdened pension schemes as they reduce benefit payments and raise contributions. Increasing labour market flexibility serves the adjustment needs of exporting industries as much as the necessary transformation towards a service economy. To the extent that flexibility measures are introduced for all employees, they might also help to bridge the increasing segmentation of the workforce in very insecure employment and the still larger segment of secure and regulated employment.

In terms of policy instruments, we can observe steps towards these issues in three major policy fields as presented in Figure 1: social policy, wage policy and labour market policy. The policy reforms in those policy fields can be summarised in a rather stylised version:

\section{(a) Transfer Payments}

Pension schemes: Reducing expenditure for state pensions by cutting benefits and extending the retirement age. Introducing new pension schemes by shifting from pay-as-you-go public schemes towards private funded pensions.

Early retirement: Reversal of policy favouring easy exit from the labour market, closing special exit schemes, limiting early retirement, reducing replacement rates, and a shift towards gradual, part-time retirement.

Unemployment benefits: A cut of unemployment benefits due to cost pressures and in order to increase work incentives (lowering of the reservation wage). Experiments with "workfare" policies and a closing off of unemployment as an early retirement route.

(b) Wage Policy

Wage moderation: Wage agreements in line with productivity increases and inflation, consideration of competitiveness vis-à-vis wage development in neighbouring countries. 
Bernhard Ebbinghaus and Anke Hassel

Public/private sector pay: De-coupling of public sector wages from private sector wage growth, caps on public sector wage bill and freezing of public sector wages. Collective bargaining system: General reform of collective bargaining system, especially the rationalisation of the hierarchy of bargaining levels, framework agreements on wage growth, and decentralisation to workplace-level bargaining.

(c) Labour Market Policies

Active employment policies: Setting up active employment creation schemes for target groups: youth, long-term unemployed, and ethnic minorities.

Employment regulation: Greater flexibility of employment contracts (allowing fixedterm contracts); introduction of temporary work agencies; flexible working time; relaxation of redundancy protection and seniority rights.

Training: Enhancing the employability of unskilled workers and young job-seekers by improving their training.

Looking at the 'bench-marking' results of the EU Commission and the OECD, it emerges that in all countries labour market regulation, collective bargaining and transfer payments have been subject to reform efforts in one way or another. Two groups of countries usually stand out in their judgement. The OECD frequently points at those countries which have been very thorough in their labour market deregulation, that is the Anglo-Saxon countries, especially the USA, UK and New Zealand. The other group, which is highlighted as being successful in reforming the labour market, consists of countries with recent tripartite concertation such as the Netherlands and Ireland.

The reform policies which result from tripartite concertation are generally very similar to the reforms in countries without concertation but which have strong liberal market traditions. Labour cost reduction, work incentives and flexibility are the dominant themes throughout all reform policies. The difference between the AngloSaxon variant of institutional welfare reform and those which are agreed by tripartite concertation lies in the degree of compensation by the government for the detrimental effects of the reforms to the working population. Tripartite agreements on labour market and welfare reforms are generally accompanied by compensatory measures sponsored by the government. For example, a number of those agreements imply that labour costs should be lowered, while the net income of individual employees should be preserved, thus governments can either reduce taxation or top up subsidies for lower incomes. In some cases, policy reforms are exclusively focused on reducing non-wage labour costs, which improves the income position of employees. With regard to flexibility and work incentives, social agreements deriving from tripartite concertation usually combine increased labour market flexibility and cuts in transfer 
payments with the creation of employment schemes, improved training and other measures which help individuals to adjust to a more flexible and more dynamic labour market.

The most recent Belgian development illustrates the compensatory role of government policies in welfare and labour market reforms through tripartite concertation. In November 1998, the Belgian trade unions and employers signed an agreement which prescribes a maximum wage increase of $5.9 \%$ for two years, although it may not be above the wage increases in neighbouring countries. At the same time, the employers committed themselves to create a certain number of jobs. Finally, the government pledged to bring down social security contributions for employers by 112 billion Belgian francs by 2004 and to reduce taxation for lower income groups (Kuntze 1998).

\section{Roads to success: the cases of the Netherlands and Italy}

We will now look at two cases which have successfully taken the road to tripartite concertation in welfare reforms: the Netherlands and Italy. Both countries managed to co-ordinate reform policies and sustained concertation for a longer period. However, they are not the only cases of tripartite concertation: social pacts can also be found in Ireland, Portugal, Norway, Finland and Denmark. In Belgium, concertation failed in 1996 but seems to have worked in 1998. Moreover, tripartite concertation did not always take the form of explicit tripartite "social pacts". In some cases, such as the Dutch and Belgian ones, it was bipartite agreements between union and employers which set off the process of concertation. In other cases, such as in Norway, it took the form of a parliamentary report which outlined the areas of policy reforms and prescribed the needed measures.

In Italy and the Netherlands, an initial agreement on pay was reached which altered the wage policy of the past. All sides agreed that traditional patterns of pay-setting would not be a sufficient instrument for dealing with the employment problem in the future. The "Accord of Wassenaar", signed in 1982 by the Dutch unions and employers, broke with the tradition of collective bargaining. "Dutch unions, impressed by soaring unemployment, convinced themselves that improving the profitability of Dutch industry was a sine qua non for whatever strategy of recovery and job growth" (Visser and Hemerjick 1997: 81). Dutch employers, in return, indicated that they were prepared to enter into negotiations on working time reduction. In Italy, a similar historic compromise was struck between the unions and the government, when the three union confederations formally accepted an end to the system of automatic wage indexation (scala mobile) in July 1992 (Regalia and Regini 1998) against the protest of large sections of their membership. 
In both countries the unions' willingness to compromise followed a series of conflicts with the government. The Dutch agreement developed after long and conflictual wage bargaining rounds in the late 1970s and early 1980s in which the government frequently intervened in wage policy. As unemployment was soaring, the trade unions pursued a strategy of collective working time reduction (as favoured by the ETUC), which was, however, vigorously rejected by the employers. In Italy, the unions staged a general strike against the abolition of the scala mobile only days before their trade union leaders signed it away.

These initial compromises by the trade unions were followed by a number of reforms on wage policy and social policy. In Italy, a year after the abolition of the scala mobile, the government and the social partners signed the Ciampi-Protocol (Regini 1997). This protocol was proposed by the Ciampi government and aimed at reorganising the hitherto fragmented bargaining system into two levels. Sectoral agreements are meant to lay down wage norms for several years on the basis of inflation forecasts. At the second, plant level, additional wage bonuses can be paid on the basis of productivity increases. The agreement also modernised the workplace-level union representation and Unitary Union Representative Structures (RSU) were introduced in order to bargain over wages at the plant level (Regalia and Regini 1998: 477). In the Netherlands, the Wassenaar Accord also marked the first step from a relatively centralised system of wage bargaining to a decentralised but co-ordinated system (Visser and Hemerijck 1997: 82). In both countries public sector pay was subject to reform and, in both cases, public sector pay was de-coupled from wage increases in the private sector (Hassel 1998: 630).

Labour market flexibility was increased by the tripartite employment pact signed by the Italian unions, employers and the government in September 1996. The pact covered employment agencies, part-time and fixed-term employment and community work. In the Netherlands, employers and unions encouraged part-time work and agency jobs which increased substantially. The increase in labour market flexibility was supported by additional employment creation schemes. In both countries, governments introduced specific work programmes for the long-term unemployed. In addition, the Netherlands introduced specially targeted programmes for ethnic minorities in 1990. In Italy, the government offered companies tax reductions if they hired young people (under the age of 32), long-term unemployed or handicapped workers. The Italian tripartite employment pact also included a reform of the vocational training system.

Moreover, the pressure on the non-active working-age population was heightened. Both welfare states suffered from an increasing share of early retired and disabled 
pensioners. In Italy, people could receive seniority pensions at any age after 35 years of service (and even earlier in the public sector). In the Netherlands, favourable disability pensions that acknowledged the labour market conditions were massively promoted by unions to ease the labour market and by employers to shed off less productive but highly protected workers. In the early 1980 s, almost $14 \%$ of the Dutch labour force received either disability or early retirement pensions (Visser and Hemerijck 1997: 9). Given the comparatively high share of transfer recipients of working age in both countries, these schemes had lowered contributions and increased transfer payments, so that pressures for old age and disability pension reforms mounted. In Italy, moderate pension reforms were negotiated with the unions by the Dini government (1995) and the Prodi government (1997), while earlier unilateral, more radical plans by the Berlusconi government had caused massive protests and strikes. In the Netherlands, disability pensions were cut and eligibility rules tightened by the government in 1987, though with not much success, and, after considerable protests and electoral losses, the government reached a compromise for social welfare reform in 1993 (Aarts and Jong 1996).

By looking at both cases, one can identify a pattern of reform which starts with moderate wage agreements, but then moves on to a range of more institutional reforms. These include a decentralisation of wage bargaining, an increase in publicly funded employment schemes, and an overhaul of the social transfer system. In both countries, the sequence of reforms was similar, starting with cost-cutting measures and moving to more complicated welfare reform issues. The Dutch and Italian governments tried to gain more influence over wage developments, in particular over wages in the public sector, compensating the union concessions by providing employment schemes and tax cuts. The changes in the social security system and cuts in transfer benefits came at a later stage and led to new conflicts with the trade unions but were ultimately resolved by social compromise.

In both countries, the reform process took the form of a sequence of tri- or bi-partite agreements most of which were instigated by the government. The reform process started with a clear commitment by the government to induce major changes in the way wage and social policies were run. Both the Dutch Lubbers government in 1982 and the Italian Amato government in 1992 were determined to hold down wage increases against the resistance of the unions.' In both cases, the government's credible threat of unilateral

\footnotetext{
${ }^{1}$ This comparison should not, however, lead to underestimation of the major differences between the position of the state in both countries: in Italy a weak political system sought, in the end, the support of weak organised interests in order to gain public legitimacy; the position of the Dutch government was, in comparison, much stronger and more convincing in terms of its powers to intervene in the collective bargaining system.
} 
intervention in wage bargaining compelled the unions to reconsider their position on pay policy. Similarly, the government intervened in the social security system and forced a compromise over much needed reform measures. The Dutch government altered the traditional self-governance of social insurance funds by the employers and unions, and imposed new tripartite or political bodies that would be more responsible in implementing and controlling social insurance schemes.

\section{Uncoordinated reform policies: the cases of Germany and France}

Let us look at two similar countries, Germany and France, which share many features of continental welfare states but which were unable to successfully negotiate a tripartite reform process over the last years. Germany may join the club of successful countries, if the new "red-green" coalition is able to follow up on its joint declaration with the social partners of December 1998 and engage in a process of further tripartite consultation. Before speculating about future developments, it might be instructive to analyse the reasons for failure in the past, as this could provide some hints on whether these obstacles can be lifted by the new consultation process.

In both countries, France and Germany, we find welfare reforms with regard to transfer payments and labour market flexibility during the 1990s. In both countries, conservative governments enacted legislation to remove rigidities on the labour market, yet this occured against the opposition of trade unions. In both countries, governments introduced employment schemes which provided large subsidies for the unemployed. The conservative Balladur government enacted a complex 'five-year' employment law in 1993 which reduced employers' social security contributions, reorganised existing employment schemes and introduced financial incentives to hire young unemployed. Similarly, the liberal-conservative government of Helmut Kohl introduced a range of measures that enhanced labour market flexibility while increasing the scope for employment schemes. However, in both countries, there has been no co-ordination between governments and social partners with regard to social policy and wage bargaining and neither explicit nor implicit co-operation in employment policy. Yet, this lack of co-operation in the two countries is due to very different reasons.

In France, as in Germany, employers and unions play an important role in the administration of social insurance. The French unemployment insurance and supplementary pensions schemes derive from collective agreements and the state, although subsidising the schemes, had traditionally only limited control. Following the election of President Chirac, the new Conservative Juppé govern- 
ment announced a massive reform package in November 1995 which provoked widespread protest. Since the special public sector schemes were also to be reformed, the state railways unions and some other public sector unions went on strike during the winter $1995 / 96$. Yet the politically fragmented union movement was also split over its position on reform: FO which had a strong position in the national sickness funds defended the status quo, the Communist CGT took a leading role in the strikes, and the moderate CFDT partly recognised the need to reform. The government invited the unions and employers to a "summit for employment" at the height of the strike wave in mid-December 1995, which concluded with a declaration that called for the integration of young people and a reduction of working time. While the government made concessions to postpone some policies, in particular concerning the special pension schemes in the public sector, it then implemented some urgent measures of the social security reform unilaterally by emergency decrees and parliamentary legislation. Most importantly, the Constitution was amended to allow the parliament to fix "expenditure targets" for the social security funds, and the board's employee majority is replaced by equal representation of employers, employees, and state appointees (Palier 1997).

Since the mid-1970s, the French state had intervened in the self-administered social security system in order to introduce cuts in the financial deficit. In 1989 , the government introduced an additional income tax at source to finance social measures and help reduce some of the employer contributions that were the highest in Europe. The French state also sets the popular minimum wage (SMIC), thereby putting a floor on negotiated wages and transfer benefits. The change of government in favour of the Left did not lead to tripartite co-ordination, even though the new Prime Minister Jospin had invited the social partners to a historic Matignon meeting in October 1997. While the unions welcomed the plans for working time reduction, the French employers' confederation CNPF threatened to withdraw from all bipartite institutions and terminate existing collective agreements. The government legislated thereafter a working time law (35-hour week as of 2000) which leaves some room for collective bargaining at sectoral or company level, though only few employers were willing to negotiate the implementation of the law.

The fundamental problem in France remains that social partners are on the one hand involved in the administration of social security funds, but on the other hand have been largely unable to take on a responsible role in the regulation of the labour market and in wage policy. Given the political fragmentation of the unions, the intransigence of private employers, and a tradition of unilateral state intervention, terms 
and conditions of employment contracts have been to a great extent determined by employers and the government as regulator, especially under the social pressures of industrial unrest. The French government has repeatedly legislated reforms of collective bargaining which aimed to enable the social partners to regulate employment conditions among themselves. The Left government of the early 1980s legislated a reform of the collective bargaining system - the Auroux law - by forcing employers to negotiate at workplace level in good faith, but this unilateral intervention had not helped to overcome the weak bargaining structure in France. Similarly, in 1996 the Robien law was passed, which tried to encourage collective bargaining on working time reductions at sector and company level by granting substantial financial support to companies. Though a number of agreements on working time reductions were concluded under this law, the government nonetheless decided to legislate a 35-hour week.

Therefore, beside the question of ideological opposition, it has been the weakness of the social partners in the regulation of the French labour market which has prevented more effective co-operation between the government and social partners in welfare reform. While governments repeatedly tried to improve the instrument of collective bargaining as a regulatory tool on the labour market, the associations were not ready to use it. As a consequence, governments frequently took over labour market regulation by way of legislation, thereby pre-empting any previous attempts at improving collective bargaining.

By contrast, the German example shows a high degree of self-regulation of the labour market by the social partners. In contrast to France, Italy and the Netherlands, the state is not allowed to intervene in wage bargaining (Tarifautonomie) and the social partners have an exclusive right to set all terms and conditions. The role of the state is confined to legislating minimum standards and a legal framework for collective agreements. Given this strong notion of collective bargaining autonomy, and given the ill-fated experience of the Konzertierte Aktion until 1977, governments and social partners in Germany have found it hardly conceivable to adopt a more co-ordinated approach in welfare policy.

An attempt to bring about a social pact was, however, made by IG Metall in November 1995. They offered moderate wage increases in exchange for an employers' commitment to create a certain number of new jobs and for government concessions on welfare cuts (Bispinck 1997). Warned by the French social unrest, the Centre-Right government invited the social partners to summit "talks", and Chancellor Kohl then declared the aim of cutting unemployment by half by 2000. During the first rounds in January and February 1996, several special joint 
agreements were reached, most notably one concerning the change from full into part-time early retirement schemes, though maintaining the status quo for older cohorts.

However, the situation changed when the government (following demands from the junior Liberal party) presented its proposal on welfare retrenchment in April, including a reduction in sick pay, a general welfare freeze, a gradual extension of retirement age, and a flexiblisation of employment contracts. The unions left the summit talks in protest and organised a campaign against the welfare cuts with the churches and welfare organisations, while the employers welcomed the government's unilateral measures. Those policies that were not subject to a vote in the second chamber passed into legislation. Among them was the sick pay law, which set pay at $80 \%$ in case of sickness, but the unilateral application of this clause by many employers in the metal industry caused widespread strikes and protests of unions against breaches of current collective agreements. In fact, the employers had to retreat in this matter, which undermined the government's reform agenda. The sick pay law shows that state intervention in collective bargaining matters remains a "tricky affair" given German labour law and the strength of unions. While the state can set minimum conditions for those that are not covered by agreements, it has limited scope to determine the content of collective agreements. Although neither a national pact, nor a sectoral agreement in the metal industry was achieved, the sectoral bargaining rounds of 1996 ended with moderate wage increases and many "Alliances for jobs" were negotiated at company level, which attempted to secure the current level of employment by concessions on wage increase and flexiblisation of working time.

The IG Metall initiative of 1995 clearly suffered from the inadequate commitment to co-operate on the government side, but even a more pro-active approach of the government would not have solved the more fundamental problem of co-ordinating social policies and wage bargaining in Germany. The new government and social partners, after having recently agreed on a declaration for an "Alliance of jobs, training and competitiveness" in December 1998, will have to cope with the problem of 'segmented autonomy' in collective bargaining and social security administration. In particular, the unions are still unwilling to subscribe to a tripartite commitment on wage moderation and defend the autonomy to bargain wages in sectoral bipartite collective agreements. In comparison to the weakness of social partners with regard to the regulation of labour markets in France, it is the strong 'segmented autonomy' of the social partners in collective bargaining which makes tripartite concertation a difficult task in Germany. 


\section{Conditions for success or failure: government intervention versus "segmented autonomy"}

Considering the conditions for success and failure, we have to ask a number of questions. First, to what extent is a crisis situation necessary to overcome the obstacles and accept painful reforms? The Netherlands suffered from a severe welfare and unemployment crisis in the late 1980s, when the "Dutch disease" became a public image as more than a million Dutch people were inactive recipients of welfare transfers. The Italian welfare state, having spent more than it was able to tax for many years, had already reached its financial limits in the 1980s and then, in the 1990s, came under severe pressure to cut its public debt and state expenditure in order to meet the Maastricht criteria for EMU. Can it be that France and Germany may not have reached the limits of an economic crisis that would be able to mobilise all political and social forces and accept the necessary reform sacrifices? Mass unemployment has reached record heights in both countries, and youth unemployment in France and joblessness in East Germany call especially for action. Moreover, both left-centre governments are committed to fight unemployment and the bench-marking process of the EU employment policy will keep both governments' action programmes under scrutiny. As crisis conditions seem to be in place, there must have been other reasons for the failure in concertation.

Thus we may ask to what degree the institutional prerequisites for tripartite concertation in welfare reform are not met in these countries. First of all, the co-ordination capacity of the system of collective organisation is a crucial precondition. The French example clearly shows that tripartite concertation depends heavily on the ability of the social partners to regulate the labour market and welfare system in a responsible way. Where social partners are too weak on the labour market and can only obstruct decisions, but have not the capacity for constructive self-regulation, governments have to retreat to unilateral reform policies. To some extent this also applies to the Anglo-Saxon countries, where trade unions did not achieve the status of publicly recognised agents on the labour market and were therefore of no constructive use when changing labour market institutions. In fact, the retrenchment of the welfare state and the flexibilisation of the labour market could only be imposed by the government when the organisational capacity of labour was weakened by the decentralisation of the collective bargaining system and the removal of union securities.

Secondly, the relationship between governments and social partners seems of crucial importance, in particular with regard to wage policy. Is the intervention of the state in wage bargaining a prerequisite for bringing employers and unions to a 
compromise? Indeed, the Dutch and Italian governments have had more possibilities to intervene: a wage freeze is a credible threat by the Dutch government, and the abolition of the scala mobile was a contentious but crucial measure in Italy. In the Netherlands, the government frequently intervened in wage policy in the years before the Accord of Wassenaar. The French state intervenes in wage bargaining but often runs into problems of implementation. The minimum wage (SMIC) is set by the French government, but both Conservative and Left governments had for political reasons merely increased it, never having been able to cut or freeze wages. While the state has been eager to foster collective bargaining by forcing employers to negotiate, it cannot determine the good faith, responsibility and coordination capacity of the bargaining partners. In Germany, the Tarifautonomie has enshrined the segmented autonomy of the bargaining parties from state intervention. Even when collective agreements are extended "erga omnes" this is subject to approval of both social partners. While the social partners have been by and large "responsible" in wage claims under the monetary policy of the independent central bank, the Bundesbank, this sets limits on political exchanges in tripartite concertation when welfare policies, taxation, wage increases and employment creations have to be weighted against one another.

Thus in contrast to neo-corporatist income policies of the 1970s, tripartite concertation in the 1990s follows a modified agenda and requires different coordination capacities of the corporate actors. While political exchange in the earlier period consisted of wage moderation in exchange for the expansion of social and employment rights, social pacts today aim at achieving a social consensus on a reform agenda with the hope of a positive impact on employment growth. For trade unions, this deal might at first glance look rather foul, since they are often asked to sign away today's regulations in exchange for possible future gains. However, experiences in the Netherlands and Italy do not suggest that trade unions are particularly unhappy with their pacts, for they continue to conclude new agreements. 


\section{References}

Aarts, L.J.M. and P.R.d. Jong (1996) 'Evaluating the 1987 and 1993 social welfare reforms From disappointment to potential success,' in L.J.M. Aarts, R.V. Burkhauser, and P.R.d. Jong (eds.) Curing the Dutch Disease. An International Perspective on Disablity Policy Reform, Aldershot Avebury, 47-69.

Bispinck, Reinhard (ed.) (1997) 'The chequered history of the Alliance for Jobs' in Guiseppe Fajertag and Philippe Pochet, eds. (1997) Social Pacts in Europe, Brussels ETUI, 63-78.

EU Commission (1993) Growth, Competitiveness, Employment. The challenges and ways forward into the 21st Century. White Paper. Luxembourg: Office for Official Publications of the EC.

EU Commission (1997) Joint Employment Report 1997, Brussels: European Union, 30 Sept. 1997.

EU Commission (1998) Joint Employment Report 1998. Brussels: European Union. Fajertag, Giuseppe and Philippe Pochet (eds.) (1997) Social Pacts in Europe, Brussels: ETUI.

Hassel, Anke (1998) 'Soziale Pakte in Europa', Gewerkschaftliche Monatshefte 10/98, 626-637.

Kuntze, O.-E. (1998) 'Neue, korporativistische Einkommenspolitik in europäischen Ländern - Anachronismus oder Standortvorteil?', ifo-schnelldienst 34-35/98, 25 43.

Lash, Scott and John Urry (1987) The End of Organized Captitalism. Cambridge: Polity Press.

OECD (1997) Implementing the OECD Jobs Strategy: Lessons from member countries'experience, Paris: OECD.

Palier, Bruno (1997) 'A 'liberal' dynamic in the transformation of the French social welfare system', in Jochen Clasen (ed.) Social Insurance in Europe, Bristol: The Policy Press, 84-106.

Pierson, Paul (1996) 'The New Politics of the Welfare State', World Politics (2), 143179.

Pochet, Philippe and Giuseppe Fajertag (1997) 'Social pacts in Europe in the 1990s. towards a European social pact?' in Giuseppe Fajertag and Philippe Pochet (eds.) Social Pacts in Europe, Brussels: ETUI, 9-25.

Regalia, Ida and Marino Regini (1998) 'Italy: The Dual Character of Industrial Relations'. In Anthony Ferner and Richard Hyman (eds.) Changing Industrial Relations in Europe, Oxford: Basil Blackwell, 459-503.

Regini, Marino (1997) 'Still Engaging in Corporatism? Recent Italian Experience in Comparative Perspective', European Journal of Industrial Relations, 3(3), 259-278. 
Rhodes, Martin (1997) Globalisation, Labour Markets and Welfare States: A Future of "Competitive Corporatism?" EUI Working Paper RSC No. 97/36. Florence: European University Institute.

Schmitter Philippe C. and Jürgen Grote (1997) The Corporatist Sisyphus: Past, Present and Future, EUI Working Paper RSC No. 97/4, Florence: European University Institute.

Schulten, Thorsten (1998) 'Tarifpolitik unter den Bedingungen der Europäischen Währungsunion: Überlegungen zum Aufbau eines taripolitischen Mehr-EbenenSystems am Beispiel der westeuropäischen Metallindustrie', WSI-Mitteilungen 51(7), 482-492.

Visser, Jelle and Anton Hemerjick (1997) 'A Dutch Miracle': Job Growth, Welfare Reform and Corporatism in the Netherlands, Amsterdam: Amsterdam University Press. 